ISSN : 0853-2710

\title{
PENINGKATAN KEMAMPUAN MENULIS PUISI DENGAN PENDEKATAN KONTEKSTUAL MELALUI TEKNIK COOPERATIVE COOPERATIVE INTEGRATED READING AND COMPOSITION (CIRC)
}

\author{
Mersty Elisabeth Rindengan \\ Universitas Negeri Manado
}

\begin{abstract}
Abstrak
Penelitian ini bertujuan untuk mengungkap dan mengetahui secara mendalam proses peningkatan kemampuan menulis puisi dengan pendekatan kontekstual melalui teknik Cooperative Integrated Reading and Composition (CIRC) dan mengetahui efektivitas penggunaan pendekatan kontekstual melalui teknik Cooperative Integrated Reading and Composition (CIRC) dalam meningkatkan kemampuan menulis puisi. Metode yang digunakan adalah penelitian tindakan Action Research yang dikembangkan oleh Kemmis dan Mc. Taggart yaitu model spiral dengan tahapan perencanaan, pelaksanaan, observasi, dan refleksi. Penelitian ini dilaksanakan di SD Negeri II Tomohon Sulawesi Utara, dengan jumlah siswa 26 orang siswa terdiri dari siswa laki-laki 12 orang dan siswa perempuan 14 orang. Hasil penelitian ini adalah: (1) secara keseluruhan bahwa proses pembelajaran kemampuan menulis puisi siswa SD Negeri II Tomohon Sulawesi Utara terlihat meningkat dari waktu ke waktu, yaitu pada tahap Pra-observasi/pre-test dengan skor sebesar 1064, pada siklus I meningkat dengan skor 1182, siklus II meningkat dengan skor 1694, siklus III atau post-test meningkat dengan skor 2184; (2) Ketuntasan belajar yang dimulai dari tes awal sampai dengan siklus III telah menunjukkan peningkatan, pada tes awal 3,85\% dan tetap pada siklus I, kemudian meningkat menjadi $11,54 \%$ hingga akhirnya meningkat menjadi $96,15 \%$ pada siklus III; (3) Pembelajan menulis puisi siswa dengan pendekatan kontekstual melalui teknik CIRC sangat dibutuhkan dalam pembelajaran Bahasa Indonesia di SD karena pendekatan kontekstual menciptakan suasana yang menyenangkan dalam belajar/active learning.
\end{abstract}

Kata kunci: menulis puisi, kontekstual, cooperative Integrated reading and composition (CIRC)

\section{Abstract}

This study aims to uncover and know in depth the process of improving the ability to write poetry using a contextual approach through Cooperatif Integrated Reading and Composition (CIRC) techniques and examine the effectiveness of the technique through the use of a contextual approach Cooperative Integrated Reading and Composition (CIRC) to improve the ability to write poetry. The method used was Action Research developed by Kemmis and Mc.Taggart, which is the spiral model with the stages of planning, implementation, observation, and reflection. This study took place in the elementary school SD II Tomohon in North Sulawesi with 26 students consisted of 12 male students and 14 female students. The results of this study are : (1) The overall learning process of poetry writing in elementary school SD II Tomohon in North Sulawesi is seen to rise over time, ie at the stage Pre-Observation/Pre-Test with a score of 1064, the first cycle increased with score of 1182, the second cycle increased with score 1694, the third cycle or Post-Test scored increased by 2184 (2) Exhaustiveness learning which begin from the beginning of the test until the third cycle has shown an increase, at 3.85\% and remain in cycle I, then increased to $11.54 \%$ and finally reached 96.15\% in the third cycle (3) Learning poetry writing by students using contextual approach through CIRC technique much needed in learning Indonesian in elementary school because the contextual approach creates a pleasant atmosphere in active learning.

Keywords: Poetry Writing,Contextual, Cooperative Integrated Reading and Composition (CIRC) 


\section{PENDAHULUAN}

Apresiasi puisi merupakan bagian yang tidak dapat dilepaskan dari pengajaran bahasa dan sastra Indonesia di sekolah. Namun, kenyataan di lapangan, kegiatan ini sering menemui berbagai kendala, baik dari pihak guru maupun siswa. Guru yang tidak menyukai sastra cenderung menghindari pembelajaran apresiasi puisi. Kalau pun mau mengajarkan, mereka akan mengajarkannya dengan sepintas lalu, dengan cara ala kadarnya, sehingga tidak menarik dan terasa sangat membosankan.

Keberadaan pembelajaran apresiasi puisi di Sekolah Dasar harus diakui masih sangat minim dan kurang atraktif. Kenyataan yang sering ditemui adalah, siswa dalam membaca puisi masih terasa dangkal, tidak ada penjiwaan. Di sisi lain lemahnya pembelajaran apresiasi puisi, karena peran guru yang kurang maksimal dalam mendemonstrasikan membaca puisi yang benar. Memahami makna puisi atau sajak menurut Pradopo (1999:2) bila dibandingkan dengan memahami prosa bukanlah hal yang mudah, terlebih pada masa sekarang puisi semakin kompleks. Hal ini disebabkan prosa itu mengikuti atau sesuai dengan struktur bahasa normatif, sedangkan puisi biasanya menyimpang dari tata bahasa normatif.

Tomkins (1994:56) berpendapat bahwa dalam menulis puisi siswa dapat menuliskan kata atau frase untuk mengekspresikan pikirannya tanpa memperhatikan rima, pengulangan atau pola-pola lain seperti jumlah baris, jumlah kata atau penggunaan tanda baca. Siswa dapat menulis puisi dengan menggunakan model yang sudah pernah dipelajari yaitu karya orang lain sebagai contoh. Pada awal menulis puisi kadang-kadang terlihat bahwa tulisan siswa seperti prosa. Antara puisi dan prosa seolah-olah tidak ada perbedaan. Hal ini tidak dipermasalahkan karena yang penting adalah siswa dibantu dalam menciptakan ungkapan yang puitis dalam menuliskan pengalamannya. Demikian juga dikatakan oleh Ellis (1989:194) bahwa dalam mengajarkan siswa untuk menulis puisi, yang penting adalah siswa memperoleh pengalaman yang puitis. Siswa dibekali untuk memilih kata dalam mengungkapkan perasaan mereka. Menulis puisi selama ini dianggap sulit bagi guru sekolah dasar di beberapa sekolah. Mereka beranggapan bahwa hanya seorang seniman yang berbakat yang bisa menulis puisi. Kebiasaan guru sekolah dasar dalam pembelajaran menlis puisi adalah siswa tidak dibimbing, mereka dibiarkan dalam pengembaraan untuk menulis sebuah puisi tanpa bimbingan guru. Hal ini menyebabkan pembelajaran menulis puisi tidak menarik.

Salah satu cara yang dapat dilakukan guru untuk menciptakan pembelajaran puisi yang menarik adalah dengan membawa anak langsung berhadapan dengan puisi, maka sehubungan dengan hal model pembelajaran apresiasi sastra khususnya menulis puisi akan digunakan pendekatan pembelajaran yaitu pendekatan kontekstual. Menurut Nurhadi (2003:15) pendekatan kontekstual memungkinkan siswa menguatkan, memperluas, menerapkan pengetahuan dan keterampilan akademik mereka dalam berbagai macam tatanan dalam sekolah dan luar sekolah agar 
siswa dapat memecahkan masalahmasalah dunia nyata atau masalahmasalah yang disimulasikan. Pendekatan kontekstual dalam pembelajaran atau yang lebih dikenal dengan sebutan Contextual Teaching and Learning (CTL) merupakan pendekatan pembelajaran yang membantu guru untuk mengaitkan antara materi ajar dengan situasi dunia nyata siswa yang dapat mendorong siswa membuat hubungan antara pengetahuan yang dipelajari dengan pemantapannya dalam kehidupan para siswa sebagai anggota keluarga/masyarakat. Hasil pembelajaran diharapkan lebih bermakna bagi anak untuk memecahkan persoalan, berpikir kritis dan melaksanakan observasi serta menarik kesimpulan dalam kehidupan jangka panjangnya. Dalam konteks itu, siswa perlu mengerti apa makna belajar, apa manfaatnya, dalam status apa mereka dan bagaimana mencapainya.

Sejalan dengan pemikiran diatas, peneliti mengadopsi implementasi pembelajaran kooperatif teknik CIRC. Menurut Robert E. Slavin (2011:16) dalam bukunya yang berjudul Cooperative Learning Teori, Riset, dan Praktik, salah satu teknik Cooperative Learning yaitu Cooperative Integrated Reading and Composition (CIRC) adalah teknik kooperatif yang komprehensif atau luas dan lengkap untuk pembelajaran membaca dan menulis pada jenjang Sekolah Dasar, SMP, dan SMA. Menggunakan pembelajaran kooperatif merubah peran guru dari peran yang berpusat pada gurunya ke pengelolaan siswa dalam kelompokkelompok kecil. Teknik CIRC ini mengupayakan adanya kerjasama, penggalian ide, menemukan data dan fakta melalui pemahaman terhadap gambar peristiwa yang disediakan, mendiskusikan hasil temuan kolaboratif, refleksi, dan perwujudan ke dalam karya berbentuk puisi. Penelitian ini bertujuan untuk mengungkap dan mengetahui secara mendalam bagaimana proses peningkatan kemampuan menulis puisi dengan pendekatan kontekstual melalui teknik cooperatif Integrated reading and composition (CIRC) dan menge-tahui efektivitas penggunaan pende-katan kontekstual melalui teknik cooperatif Integrated reading and composition (CIRC) dalam mening-katkan kemampuan menulis puisi.

Secara etimologi puisi berasal dari kata yunani poeima 'membuat' atau poesis 'pembuatan' dan dalam bahasa inggris disebut poem atau poetry Aminudin (2000:134). Puisi diartikan 'membuat' dan 'pembuatan' karena lewat puisi pada dasrnya seorang telah menciptakan suatu dunia tersendiri, yang mungkin berisi pesan atau gambaran suasana-suasana tertentu, baik fisik maupun batiniah. Definisi lain tentang puisi menurut Suyati (2000:3) puisi adalah sebentuk pengucapan bahasa yang memperhitungkan adanya aspekaspek bunyi di dalamnya, yang mengungkapkan pengalaman baik yang bersifat imajinatif, emosional, dan intelektual penyair yang diambil dari kehidupan individual dan sosialnya; yang diungkapkan dengan teknik pilihan tertentu, sehingga puisi itu mampu membangkitkan pengalaman tertentu pula dari diri pembaca atau dari pendengarpendengarnya. Selanjutnya, pengertian puisi menurut Coloridge (1998:1) bahwa puisi merupakan kata-kata terindah (poetry is the best world in 
the best order) kata-kata yang dipilih adalah dalam komposisi yang indah dan bernilai seni (arts). Puisi dapat pula didefinisikan sebagai bahasa tertentu yang dapat mengungkapkan lebih dalam makna dari pada bahasa biasa. Puisi adalah karya sastra yang paling padat karena mampu mengungkapkan maknanya dalam sejumlah kata minimalis. Kekuatan bahasa pada puisi mampu memberi efek yang dahsyat bagi pembacanya. Hal ini menurut Perrine (1969:9) diibaratkan sebagai voltase tinggi yang dahsyat bagi pembacanya.

"Poetry might defined is a kind of language that says more says more and says it more intensely than does ordinary language. Poetry is the most condensed and concentrated form of literature saying most in the fewest number of words.It is language whose individual lines, either because of their own brilliance or because they focus powerfuuly what has gone before, have higher voltage than most language has. It is language that grows frequently incandescent, giving off both light and heat".

Unsur-unsur puisi yang paling penting terdiri dari dua unsur, yaitu unsur tematik atau unsur se-mantik puisi dan unsur sintaksis puisi. Unsur tematik atau unsur se-mantik puisi menuju ke arah struktur batin sedangkan unsur sintaksis mengarah pada struktur puisi. Struktur batin adalah makna yang terkandung dalam puisi yang tidak secara langsung dapat dihayati. Struktur batin terdiri dari tema, perasaan, nada dan suasana, dan amanat atau pesan. Struktur fisik adalah struktur yang bisa kita lihat melalui bahasanya yang tampak. Struktur fisik terdiri dari diksi, pengimajian, bahasa figuratif atau majas, dan rima dan ritme, tipografi, dan enjambemen dan unsur batin puisi (tema, rasa, nada, dan amanat) (Waluyo, 1991:27).

Puisi dalam sastra Indonesia banyak ragamnya. Untuk pemilihan bahan pengajaran yang tepat, kita perlu mengenal keanekaragaman itu. Dengan mengenal dan memahami macam-macam puisi, baik dari sejarah perkembangan, bentuk, isi, corak, penafsiran, maupun temanya diharapkan membantu siswa dalam menangkap tema, nilai keindahan bahasa, dan isi sebuah puisi. :

1. Berdasarkan sejarah perkembangannya, terdiri atas puisi lama, puisi baru, puisi modern, dan puisi kontemporer.

2. Berdasarkan bentuknya terdiri atas, puisi lama (pantun, syair, gurindam, seloka, dan rubai), puisi baru (distikon, tersina, kuatrain, kuin, sektet, septima, oktaf, dan soneta), puisi modern, puisi kontemporer (puisi tanpa kata, puisi mini kata, dan puisi), campuran berbagai bahasa, puisi mantra, puisi tipografi, dan puisi lugas/mbeling.

3. Berdasarkan isinya terdiri atas, himne, odem, satire, elegi dan romance.

4. Berdasarkan coraknya terdiri atas, puisi lirik, puisi naratif, puisi deskriptif, puisi didaktis, humor, dan dramatik.

5. Berdasarkan penafsirannya terdiri atas, puisi diaphan, puisi 
prismatis, puisi gelap, dan puisi abstrak.

6. Berdasarkan tema terdiri atas puisi universal dan puisi restricted.

Unsur-unsur puisi menurut Aminudin (1990:7) yang paling penting terdiri dari dua unsur, yaitu unsur tematik atau unsur semantik puisi dan unsur sintaksis puisi. Unsur tematik atau unsur semantik puisi menuju ke arah struktur batin se-dangkan unsur sintaksis mengarah pada struktur puisi. Struktur batin adalah makna yang terkandung da-lam puisi yang tidak secara langsung dapat dihayati. Struktur batin terdiri dari tema, perasaan, nada dan suasa-na, amanat atau pesan. Struktur fisik adalah struktur yang bisa kita lihat melalui bahasanya yang tampak. Struktur fisik terdiri dari diksi, peng-imajian, bahasa figuratif atau majas, dan rima. Menulis puisi menurut Djojosuroto (2009:33) adalah menulis puisi merupakan sarana yang cukup efektif untuk menyampaikan pesan kepada para pembacanya karena lewat puisi dinilai "indah" kadangkala disebabkan oleh beberapa hal, misalnya inovasi-inovasi dalam pengucapan, pemilihan teknik dan ketepatan ekspresinya. Ada beberapa Menulis puisi sebagai sebuah proses kreatif memerlukan adanya kesabaran dan adanya focus dan konsentrasi yang baik. Seperti dinyatakan oleh Carter (2010: 14) sebagai berikut.

In one sense, poetry writing requires a lot of patienceperhaps more so than writing fiction or non-fiction-as more time is spent concentrating on the smaller details. With a poem you are focusing upon individual word and phrases stanzas, or even the combi- nator the ondering of the lines and the stanzas, or even te combination of ord sounds or the number of beats in a particular line.

Sayuti (2005:2) menganjurkan beberapa langkah dalam menulis puisi yaitu tahap preparasi atau persiapan, tahap inkubasi atau pengendapan, tahap iluminasi, dan tahap verifikasi atau tinjauan secara kritis.

Dari uraian di atas dapat disimpulkan bahwa dasar dari menulis puisi yaitu seseorang mempunyai kemampuan untuk menentukan tema, dapat mengekspresikan gagasan, menjelaskan tentang sikap yang ingin kita ungkapkan dalam puisi, menyampaikan pesan, dan sese-orang dapat melihat pengalaman hidupnya atau lingkungannya seba-gai sumber untuk tulisan.

Pembelajaran dengan pendekatan kontekstual (Contextual Teaching and Learning) adalah konsep belajar yang membantu guru mengaitkan antara materi yang dibelajarkan dan situasi dunia nyata siswa serta mendorong siswa membuat hubungan antara pengetahuan yang dimilikinya dan penerapannya dalam kehidupan mereka sehari-hari, dengan melibatkan tujuh komponen utama pembelajaran efektif, yakni: konstruktivisme (Constructivism), bertanya (Questioning), menemukan (Inkuiri), masyarakat belajar (Learning Community), pemodelan (Modeling), refleksi (Reflection), dan penilaian sebenarnya (Authentic Assessment). Pendekatan kontekstual menurut Nurhadi (2003:5) merupakan sebuah proses pendidikan yang bertujuan menolong para siswa melihat makna didalam materi akademik 
yang mereka pelajari dengan cara menghubungkan subjek-subjek akademik dengan konteks dalam kehidupan keseharian mereka, yaitu dengan konteks keadaan pribadi, sosial, dan budaya mereka

Pengertian pembelajaran kooperatif menurut Suprijono (2010: 54), adalah konsep yang lebih luas meliputi semua jenis kerja kelompok termasuk bentuk-bentuk yang dipimpin oleh guru atau diarahkan oleh guru". Pembelajaran kooperatif merupakan suatu pembelajaran kelompok dengan jumlah peserta didik 2-5 orang dengan gagasan untuk saling memotivasi antara anggotanya untuk saling membantu agar tercapainya suatu tujuan pembelajaran yang maksimal. Pembelajaran kooperatif merupakan salah satu model pembelajaran yang menganut paham konstruktivisme. Lima model pembelajaran tim siswa telah dikembangkan dan diteliti secara luas, terdapat tiga model pembelajaran kooperatif umum yang cocok untuk hampir seluruh mata pelajaran dan tingkat kelas: Students Teams Achievement Division (STAD), Teams-GamesTournament (TGT), dan Jigsaw. Dua yang lain merupakan kurikulum koprehensif yang dirancang untuk digunakan pada mata pelajaran tertentu pada tingkat kelas tertentu: Cooperative Reading and Composition (CIRC) untuk pengajaran membaca dan menulis di kelas II VIII dan Team Accelerated Instruction (TAI) untuk matematika pada Kelas III VI. Model-model ini seluruhnya menerapkan penghargaan tim, tanggung jawab individual, dan kesempatan yang sama untuk berhasil, namun dilakukan dengan cara-cara yang berbeda.
Pembelajaran kooperatif menuntut guru untuk berperan relatif berbeda dari pembelajaran tradisional. Berbagai peran guru dalam pembelajaran kooperatif tersebut dapat dikemukakan sebagai berikut: a) merumuskan tujuan pembelajaran, b) menentukan jumlah kelompok dalam kelompok belajar, c) menentukan tempat duduk siswa, d) merancang bahan untuk meningkatkan saling ketergantungan positif, e) menentukan peran serta untuk menunjang saling ketergantungan positif, f) menjelaskan tugas akademik, g) menjelaskan kepada siswa mengenai tujuan dan keharusan bekerja sama, h) menyusun akuntabilitas indivi-dual, i) menyusun kerja sama antar kelompok, j) menjelaskan kriteria keberhasilan, k) menjelaskan perilaku siswa yang diharapkan, 1) memantau perilaku siswa, m) memberikan bantuan kepada siswa dalam menyelesaikan tugas, n) melakukan intervensi untuk mengajarkan keterampilan bekerja sama, o) menutup pelajaran, p) Menilai kerja sama antar anggota kelompok.

Menurut Slavin $(2005: 16)$
dalam bukunya yang berjudul Cooperative Learning Teori, Riset, dan Praktik, salah satu teknik Cooperative Learning yaitu Cooperative Integrated Reading and Composition. Cooperative Integrated Reading and Composition (CIRC) adalah teknik kooperatif yang komprehensif atau luas dan lengkap untuk pembelajaran membaca dan menulis pada jenjang Sekolah Dasar, SMP, dan SMA. Pengembangan Cooperative Integrated Reading and Composition (CIRC) yang secara simultan difokuskan pada kurikulum dan metode pengajaran, yang meru- 
pakan sebuah upaya untuk menggunakan pembelajaran kooperatif sebagai sarana untuk memperkenalkan teknik terbaru latihan-latihan kurikulum yang berasal dari penelitian dasar mengenai pengajaran praktis pelajaran membaca dan menulis.

Pengembangan Cooperative Integrated Reading and Composition (CIRC) dihasilkan dari sebuah analisis masalah-masalah tradisional dalam pengajaran membaca, menulis, dan seni berbahasa. Model pembelajaran CIRC menurut Slavin memiliki delapan komponen sebagai berikut:

1. Teams, yaitu pembentukan kelompok heterogen yang terdiri dari 4 atau 5 peserta didik.

2. Placement tes, misalnya diperoleh dari rata-rata nilai ulangan harian sebelumnya atau berdasarkan kelebihan dan kelemhan peserta didik pada bidang tertentu.

3. Student creative, melaksanakan tugas dalam suatu kelompok dengan menciptakan situasi di mana keberhasilan individu ditentukan atau dipengaruhi oleh keberhasilan kelompokknya.

4. Team study, yaitu tindakan belajar yang harus dilaksanakan oleh kelompok.

5. Team scorer and team recognition yaitu pemberian skor terhadap hasil kerja kelompok dan memberikan kriteria penghargaan terhadap kelompok yang berhasil secara cemerlang dan kelompok yang dipandang kurang berhasil.

6. Teaching group, pemberian tugas kelompok.

7. Fact tes yaitu pelaksanaan tes atau ulangan berdasarkan fakta yang diperoleh peserta didik.
8. Whole-class units, yaitu pemberian rangkuman materi oleh guru diakhir waktu Suyitno (2005:3-4).

Dari uraian diatas dapat disimpulkan bahwa pembelajaran kooperatif tipe CIRC dari segi bahasa dapat diartikan sebagai suatu model pembelajaran kooperatif dengan suatu program komprehensif atau luas dan lengkap untuk pengajaran membaca dan menulis untuk kelas-kelas tinggi sekolah dasar yang mengintegrasikan suatu bacaan secara menyeluruh kemudian mengkomposisikannya menjadi bagian-bagian yang penting.

\section{METODE}

Penelitian ini merupakan penelitian tindakan (action research) Penelitian tindakan menurut Hopkins dalam Emzir (2008:233) adalah proses yang dirancang untuk memberdayakan partisispan dalam proses (siswa, guru, dan peserta lainnya) dengan maksud untuk meningkatkan pengalaman pendidikan. Pendekatan kuantitatif digunakan untuk menganalisis data hasil proses belajar mengajar atau membandingkan nilai peserta didik sebelum dan sesudah tindakan dilakukan. Nilai akan diuji kebenarannya melalui metode tersebut untuk melihat seberapa besar signifikansi peningkatan nilai sebelum dan sesudah dilakukan tindakan. Penelitian ini menggunakan desain Kemmis dengan tahapan perencanaan, pelaksanaan, observasi, dan refleksi.

Penelitian ini mengambil lokasi di SD Negeri II Tomohon Sulawesi Utara. Penelitian dimulai pada semester ganjil yaitu bulan Agustus 2012 sampai bulan November 2012. Penelitian ini dilaksanakan selama 3 
bulan mengikuti jadwal di sekolah tersebut.

Produk puisi dinilai menggunakan penilaian berdasarkan model penilaian dari Harris dan Halim yang digabungkan dengan model ESL yang telah dimodifikasi Nurgiyan-toro

\begin{tabular}{|c|c|c|c|}
\hline Aspek & Kriteria & Indikator & Skor \\
\hline \multirow[t]{4}{*}{ Tema } & \multirow[t]{4}{*}{$\begin{array}{l}\text { Kesesuaian tema } \\
\text { dengan isi puisi }\end{array}$} & $\begin{array}{l}\text { SANGAT BAIK : isi sangat sesuai dengan tema } \\
\text { yang ditentukan-isi sangat sesuai dengan judul } \\
\text { puisi-pemilihan judul kreatif. }\end{array}$ & 5 \\
\hline & & $\begin{array}{l}\text { BAIK : isi sesuai dengan tema yang ditentukan- } \\
\text { isi sesuai dengan judul puisi-judul kurang kreatif }\end{array}$ & 4 \\
\hline & & $\begin{array}{l}\text { CUKUP BAIK : isi puisi kurang relevan dengan } \\
\text { tema yang ditentukan-isi puisi kurang sesuai } \\
\text { dengan judul puisi-judul kurang kreatif }\end{array}$ & 3 \\
\hline & & $\begin{array}{l}\text { KURANG BAIK : isi tidak relevan dengan tema } \\
\text { dan judul puisi }\end{array}$ & 2 \\
\hline \multirow[t]{4}{*}{ Gagasan } & \multirow[t]{4}{*}{$\begin{array}{l}\text { Kedalaman } \\
\text { gagasan }\end{array}$} & $\begin{array}{l}\text { SANGAT BAIK : pemilihan gagasan tepat- } \\
\text { sesuai dengan tema yang diangkat-penggunaan } \\
\text { kata efektif-bahasa padat }\end{array}$ & 5 \\
\hline & & $\begin{array}{l}\text { BAIK : pemilihan kata tepat- sesuai dengan tema } \\
\text { yang diangkat - penggunaan kata efektif-bahasa } \\
\text { kurang padat }\end{array}$ & 4 \\
\hline & & $\begin{array}{l}\text { CUKUP BAIK : pemilihan kata tepat- kurang } \\
\text { sesuai dengan tema yang diangkat kata efektif- } \\
\text { bahasa padat }\end{array}$ & 3 \\
\hline & & $\begin{array}{l}\text { KURANG BAIK : pemilihan kata kurang tepat- } \\
\text { tidak sesuai dengan tema yang diangkat - } \\
\text { penggunaan kata kurang efektif-bahasa kurang } \\
\text { padat }\end{array}$ & 2 \\
\hline \multirow[t]{4}{*}{ Diksi } & \multirow[t]{4}{*}{ Ketepatan Diksi } & $\begin{array}{l}\text { SANGAT BAIK : pemilihan kata tepat-tidak } \\
\text { bersifat keseharian-penggunaan kata efektif- } \\
\text { bahasa padat }\end{array}$ & 5 \\
\hline & & $\begin{array}{l}\text { BAIK : pemilihan kata tepat-tidak bersifat } \\
\text { keseharian- penggunaan kata efektif-bahasa } \\
\text { kurang padat }\end{array}$ & 4 \\
\hline & & $\begin{array}{l}\text { CUKUP BAIK : pemilihan kata tepat-bersifat } \\
\text { keseharian-penggunaan kata efektif-bahasa } \\
\text { padat }\end{array}$ & 3 \\
\hline & & $\begin{array}{l}\text { KURANG BAIK : pemilihan kata kurang tepat- } \\
\text { bersifat keseharian-penggunaan kata kurang } \\
\text { efektif-bahasa kurang padat }\end{array}$ & 2 \\
\hline \multirow[t]{4}{*}{ Tipografi } & \multirow[t]{4}{*}{$\begin{array}{l}\text { Pemanfaatan } \\
\text { Tipografi }\end{array}$} & $\begin{array}{l}\text { SANGAT BAIK : adanya penyampaian amanat- } \\
\text { jelas-dapat dimengerti }\end{array}$ & 5 \\
\hline & & $\begin{array}{l}\text { BAIK : adanya penyampaian amanat-kurang } \\
\text { jelas-kurang dapat dimengerti }\end{array}$ & 4 \\
\hline & & $\begin{array}{l}\text { CUKUP BAIK : adanya penyampaian amanat- } \\
\text { tidak jelas-tidak dapat dimengerti }\end{array}$ & 3 \\
\hline & & $\begin{array}{l}\text { KURANG BAIK : tidak ada penyampaian } \\
\text { amanat baik tersirat maupun tersurat }\end{array}$ & 2 \\
\hline
\end{tabular}

(2001:307). Rincian tiap-tiap aspek terdapat dalam tabel 1 berikut: 
BAHTERA: Jurnal Pendidikan Bahasa dan Sastra, Volume 16 Nomor 1 Januari 2017 http://journal.unj.ac.id/unj/index.php/bahtera/

ISSN : 0853-2710

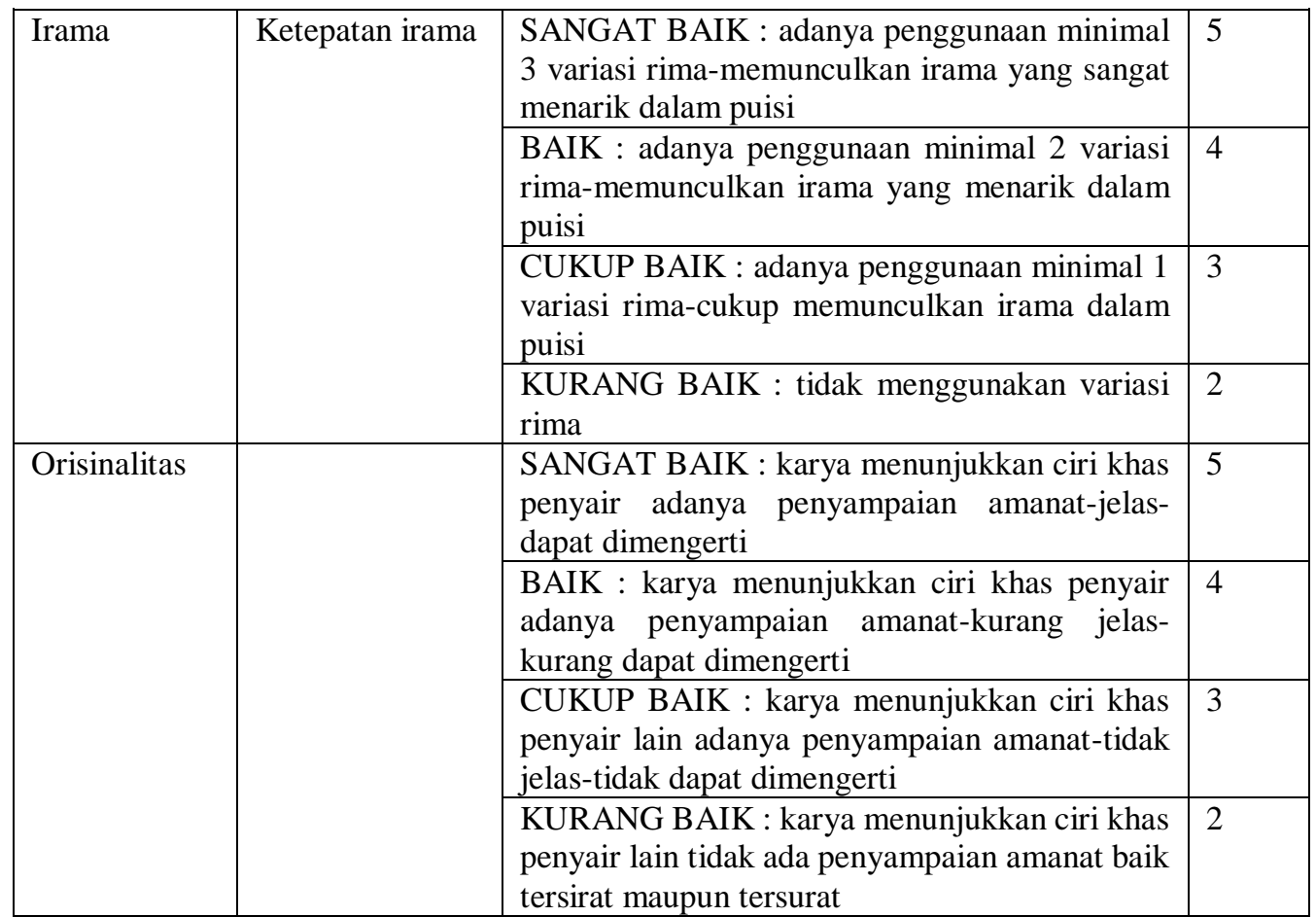

\section{HASIL DAN PEMBAHASAN}

Secara garis besar hasil penelitian mengenai kemampuan menulis puisi siswa dengan pende- katan kontekstual melalui teknik CIRC Siswa SDN II Tomohon Sulawesi Utara dapat secara detail perkembangan tersebut dapat dilihat dari setiap aspek sebagai berikut:

Tabel 2. Data Proses Pembelajaran Menulis Puisi

\begin{tabular}{|l|c|c|c|c|c|c|c|c|}
\hline \multirow{2}{*}{ Kategori } & \multicolumn{2}{|c|}{ Pre-test } & \multicolumn{2}{c|}{ Siklus I } & \multicolumn{2}{c|}{ Siklus II } & \multicolumn{2}{c|}{ Siklus III } \\
\cline { 2 - 9 } & F & \% & F & $\%$ & F & $\%$ & F & $\%$ \\
\hline Amat Baik & 0 & $0,00 \%$ & 0 & $0,00 \%$ & 0 & $0,00 \%$ & 1 & $3,85 \%$ \\
\hline Baik & 0 & $0,00 \%$ & 4 & $15,38 \%$ & 13 & $50,00 \%$ & 24 & $92,31 \%$ \\
\hline Cukup Baik & 2 & $7,69 \%$ & 9 & $34,62 \%$ & 11 & $42,31 \%$ & 1 & $3,85 \%$ \\
\hline Sedang & 5 & $19,23 \%$ & 0 & $0,00 \%$ & 2 & $7,69 \%$ & 0 & $0,00 \%$ \\
\hline Kurang Baik & 19 & $73,08 \%$ & 13 & $50,00 \%$ & 0 & $0,00 \%$ & 0 & $0,00 \%$ \\
\hline
\end{tabular}

Selanjutnya, dapat dilihat bahwa peningkatan hasil pengamatan kegiatan belajar siswa mulai dari kegiatan pretest hingga siklus III. Hasil pengamatan kegiatan siswa pada saat Siklus I dapat dilihat dari hasil analisis sebagai berikut: siswa yang berkriteria penilaian Amat Baik adalah belum ada, berkriteria Baik 4 orang atau $15,38 \%$, berkrite-ria Cukup Baik 9 orang atau 34,62\%, berkriteria Sedang belum ada dan Kurang Baik 13 orang atau 50\%.

Hasil pengamatan kegiatan siswa pada saat Siklus II dapat dilihat dari hasil analisis sebagai 
berikut: siswa yang berkriteria penilaian Amat Baik adalah belum ada, berkriteria Baik 12 orang atau 46,15\%, berkriteria Cukup Baik 11 orang atau $42,31 \%$, berkriteria Sedang 2 orang atau 7,69\% dan $\mathrm{Ku}-$ rang Baik 1 orang atau 3,85\%. Hasil pengamatan kegiatan siswa pada saat Siklus III dapat dilihat dari hasil analisis sebagai berikut: siswa yang berkriteria penilaian Amat Baik adalah 1 orang atau $3,85 \%$, berkriteria Baik 24 orang atau 92,31\%, berkriteria Cukup Baik 1 orang atau 3,85\%, berkriteria Sedang tidak ada dan Kurang Baik tidak ada. Hasil pengamatan dapat dilihat peningkatannya pada grafik dibawah ini:

Grafik 1. Pengamatan Kegiatan Siswa Siklus I sampai dengan Siklus III

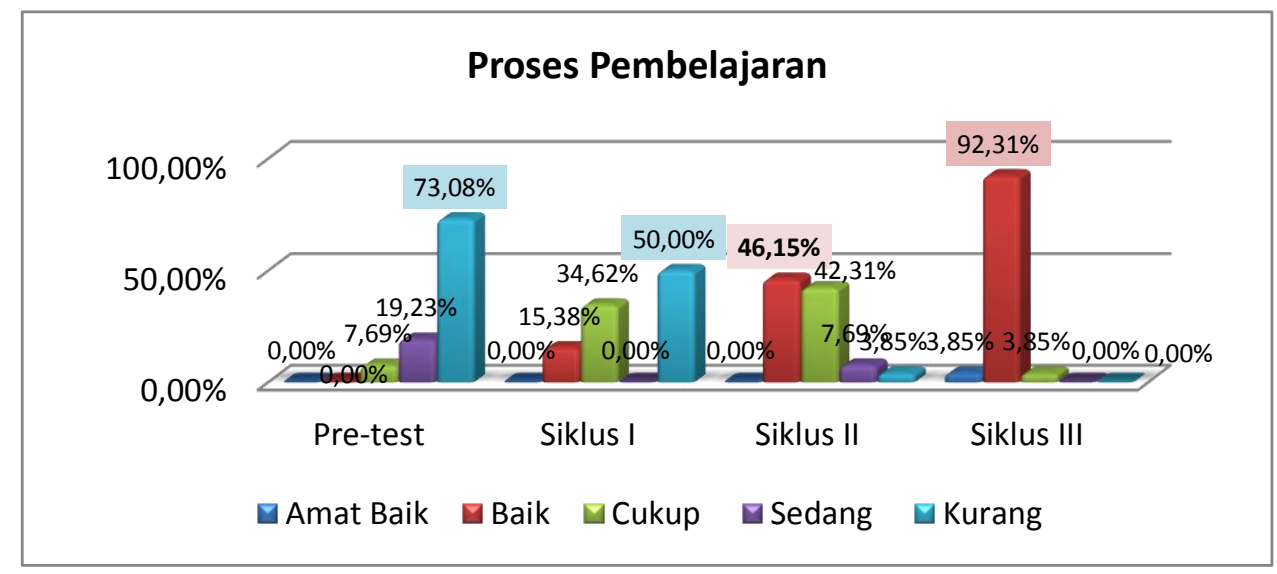

Berdasarkan data pengamatan kegiatan siswa dalam Proses pembelajaran menulis puisi mulai dari tahap praobservasi sampai dengan siklus III dapat disimpul-kan sudah mengalami peningkatan yang signifikan. Siswa sudah dapat mengembangkan pemikiran, dan gagasan mereka dalam menulis puisi. Hal ini sejalan dengan konsep belajar kontekstual di mana guru menghadirkan situasi dunia nyata ke dalam kelas dan mendorong siswa membuat membuat hubungan antara pengetahuan yang dimiliki-nya dengan penerapannya dalam

Tabel 3. Proses Pembelajaran Menulis Puisi

\begin{tabular}{|c|c|c|}
\hline Siklus & Perolehan & Peningkatan \\
\hline Pretest & $40,92 \%$ & - \\
\hline Siklus I & $54,15 \%$ & $13,23 \%$ \\
\hline
\end{tabular}


BAHTERA: Jurnal Pendidikan Bahasa dan Sastra, Volume 16 Nomor 1 Januari 2017 http://journal.unj.ac.id/unj/index.php/bahtera/

ISSN : 0853-2710

\begin{tabular}{|c|c|c|} 
Siklus II & $72,15 \%$ & $18,00 \%$ \\
\hline Siklus III & $84,00 \%$ & $11,85 \%$ \\
\hline
\end{tabular}

Berdasarkan data di atas dapat belajar siswa mengalami peningdisimpulkan bahwa hasil penilaian katan.

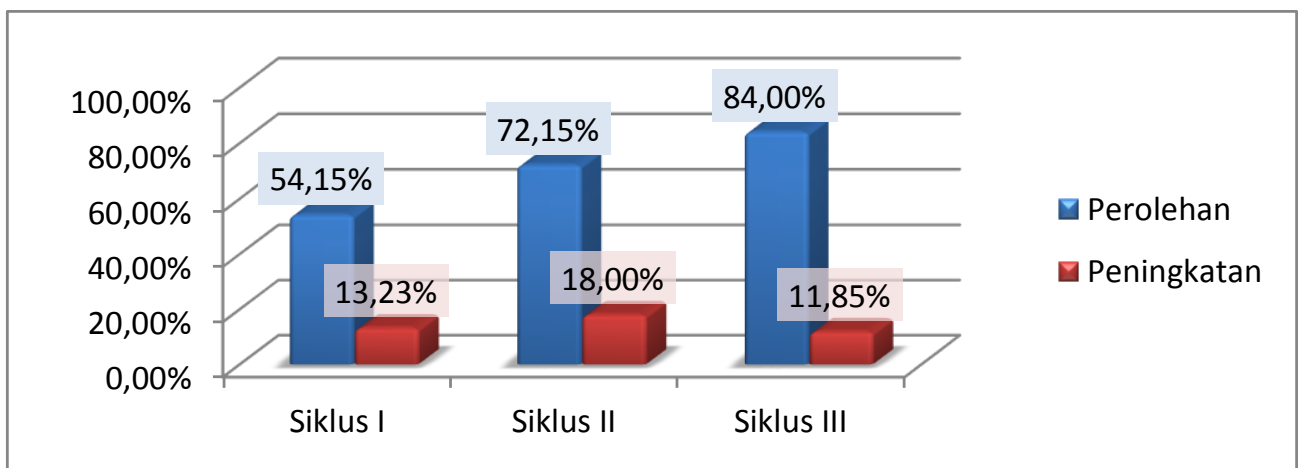

Grafik 2. Penilaian Pembelajaran Menulis Puisi

Berdasarkan hasil penilaian guru, ketuntasan belajar yang dimulai dari tes awal sampai dengan siklus III telah menunjukkan pening-katan. Adapun peningkatan hasil tersebut dapat diuraikan sebagai beri-kut: nilai ketuntasan siswa pada tes awal 3,85\% dan tetap pada siklus I, kemudian meningkat menjadi $11,54 \%$ hingga akhirnya meningkat menjadi $96,15 \%$ pada siklus III. Dengan demikian peningkatan ke-tuntasan hasil belajar siswa dapat dilihat pada grafik dibawah ini:

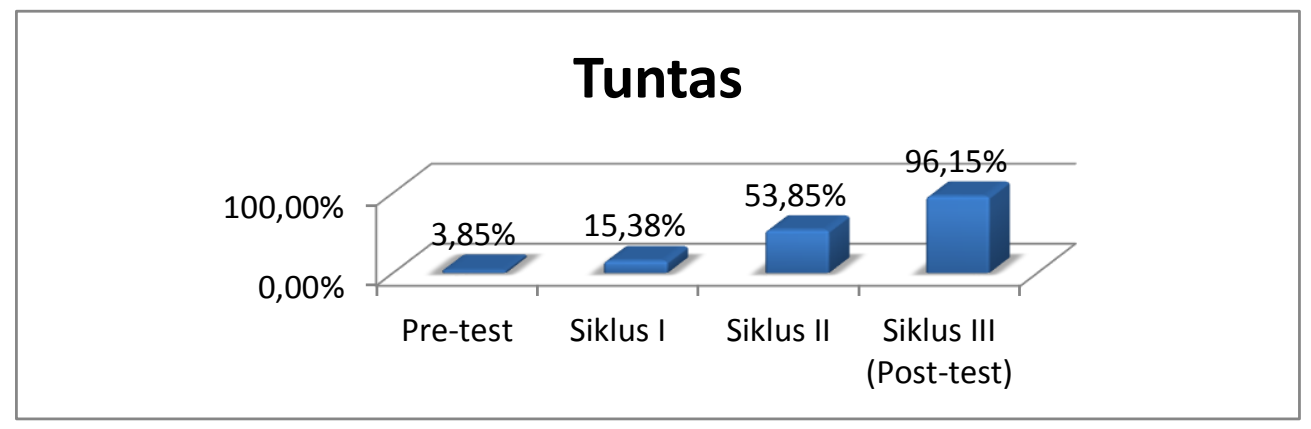

Grafik 3. Nilai ketuntasan belajar

Analisis Uji Perbandingan Antara Sebelum dan Sesudah Pendekatan Kontekstual

Untuk membuktikan bahwa data sebelum dan sesudah pendekatan Kontekstual berbeda atau tidak secara signifikan, maka dilakukan uji kesamaan dua nilai rata-rata keadaan awal dengan mengguna-kan metode uji-t. Metode uji-t berpasangan merupakan analisis parametrik dimana terdapat asumsi yang harus terpenuhi terlebih dahulu, yaitu normalnya distribusi masing-masing kelompok data yang kemu-dian akan diolah. Apabila normalitas data terpenuhi, selanjutnya dilakukan perhitungan nilai gain yang akan 
digunakan dalam uji perbandingan rata-rata (uji-t). Namun, permasalahan terjadi ketika asumsi tidak terpenuhi. Karena kita tidak selalu dapat membuat asumsi itu, dan memang dalam beberapa contoh data tidak dapat dibuat asumsi, maka kita dapat menganalisis data dengan metode yang dikenal sebagai metode nonparametrik atau metode tanpa distribusi. Uji peringkat bertanda Wilcoxon untuk data berpasangan dapat dipakai untuk menguji perbedaan antara kedua kelompok data tersebut. Pengujian merupakan alternatif lain untuk uji-t parametrik yang paling berguna apabila peneliti ingin menghindari asumsi-asumsi dan persyaratan-persyaratan yang membatasi, yang semuanya itu diperlukan dalam uji-t (Siegel, Sidney. Alih Bahas. Sayuti (1997:159).

\section{Uji Normalitas}

Uji normalitas yang digunakan adalah metode uji normal Kolmogorov-Smirnov. Berikut disajikan secara lengkap perhitungan hasil uji normalitas skor kemampuan menulis puisi sesudah pendekatan kontekstual untuk tiap-tiap aspek.

Tabel 4. Uji Normalitas

\begin{tabular}{|ll|r|r|}
\hline & \multicolumn{1}{c|}{$\begin{array}{c}\text { Sebelum } \\
\text { Pendekatan } \\
\text { Kontekstual }\end{array}$} & $\begin{array}{c}\text { Sesudah } \\
\text { Pendekatan } \\
\text { Kontekstual }\end{array}$ \\
\hline $\mathrm{N}$ & 26 & 26 \\
Normal Parameters a,b & Mean & 40.9231 & 84.0000 \\
& Std. Deviation & 15.02777 & 5.06754 \\
Most Extreme & Absolute & .125 & .191 \\
Diff erences & Positive & .125 & .191 \\
& Negativ e & -.107 & -.155 \\
Kolmogorov-Smirnov Z & & .635 & .974 \\
Asy mp. Sig. (2-tailed) & & .815 & .299 \\
\hline
\end{tabular}

a. Test distribution is Normal.

b. Calculated from data.

Dari perhitungan diperoleh nilai Asymp.Sig. (2-tailed) sebesar 0,815 pada data Kemampuan Menulis Puisi Sebelum Pendekatan Kontekstual dan Kemampuan Menulis Puisi sesudah Pendekatan Kontekstual sebesar 0,299. dikarenakan kedua nilai tersebut lebih besar daripada alpha (Asymp.Sig.> 0,05), sehingga dapat disimpulkan bahwa skor Kemampuan Menulis Puisi Sebelum dilakukan Pendekatan Kontekstual melalui teknik CIRC dan Kemampuan Menulis Puisi Sesudah Pendekatan Kontekstual Pendekatan
Kontekstual melalui teknik CIRC berdistribusi normal.

Dari hasil uji normalitas terhadap kelompok-kelompok data tersebut di atas dapat diketahui bahwa tidak terdapat pelanggaran terhadap asumsi pengujian parametrik. Oleh sebab itu pengujian akan dilakukan menggunakan metode parametrik, dalam hal ini menggunakan uji-t sampel berpasangan.

\section{Uji-t Sampel Berpasangan}

Uji-t berpasangan (paired $t$ test) adalah salah satu metode 
pengujian hipotesis dimana data yang digunakan tidak bebas (berpasangan). Ciri-ciri yang paling sering ditemui pada kasus yang berpasangan adalah satu individu (objek penelitian) dikenai 2 buah perlakuan yang berbeda. Walaupun menggunaPengujian hipotesis:

$\mathrm{H}_{0}$ : Kedua kelompok data cenderung sama (tidak berbeda signifikan)

$\mathrm{H}_{1}$ : Kedua kelompok data cenderung tidak sama (berbeda signifikan)

A : $5 \%$

Kriteria uji: kan individu yang sama, peneliti tetap memperoleh 2 macam data sampel, yaitu data dari perlakuan pertama dan data dari perlakuan kedua. Perlakuan pertama mungkin saja berupa kontrol, yaitu tidak memberikan perlakuan sama sekali terhadap objek penelitian.

Tolak $\mathrm{H}_{0}$ jika $p$-value $<\alpha$

Terima $\mathrm{H}_{0} \mathrm{jika} p$-value $<\alpha$

Dengan bantuan Aplikasi Program SPSS versi 13.0 didapat output hasil perhitungan sebagai berikut:

Tabel 5. Uji-t Sampel Berpasangan Kemampuan Menulis Puisi

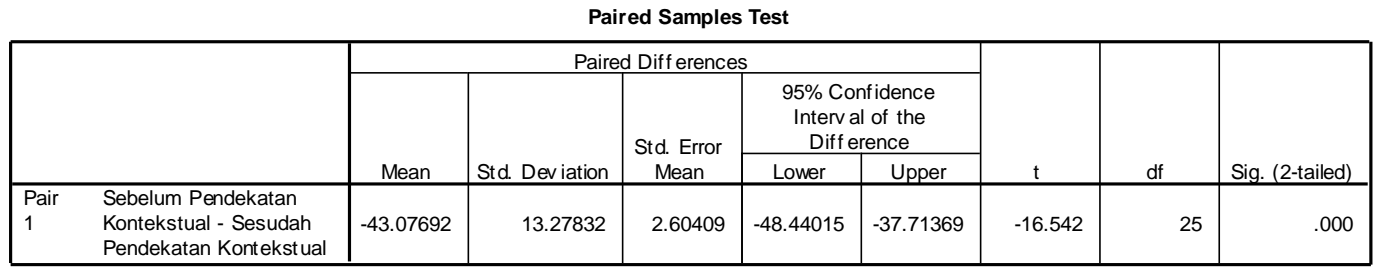

Dari tabel di atas menunjukkan bahwa nilai $p$-value yang didapat adalah sebesar 0,000. Jika dibandingkan dengan alpha, nilai tersebut lebih kecil $(0,000<0,05)$ yang menyatakan $\mathrm{H}_{0}$ ditolak. Hal ini menandakan bahwa terdapat perbedaan yang signifikan antara data Kemampuan Menulis Puisi Sebelum Pendekatan Kontekstual dan Kemampuan Menulis Puisi Sesudah Pendekatan Kontekstual.

Dari hasil penelitian dengan membandingkan hasil pada setiap siklus, maka terlihat adanya peningkatan yang baik pada hasil belajar siswa, pada mata pelajaran Bahasa Indonesia pokok bahasan Apresiasi Puisi "menulis puisi" di SD Negeri II Tomohon dengan menggunakan model pembelajaran Coopertive Integrated Reading and Composition (CIRC).
Melihat data yang ada pada siklus I tentang tingkat keberhasilan siswa belum memperoleh hasil yang optimal, pada siklus I ini, peneliti mengharapkan cara belajar dengan menggunakan model pembelajaran Cooperatif Integrated Reading and Composition sebagai pendekatan pembelajaran, dimana dalam menjelaskan apresiasi puisi lebih khusus dalam membaca puisi, guru (peneliti) memberikan contoh puisi serta bagaimana cara membacakan puisi dengan menggunakan intonasi dan lafar yang benar, agar ketika siswa membacakan puisi bisa membacakan dengan baik dan benar.

Dengan memberikan dorongan dan penghargaan berupa tepuk tangan ataupun dengan memberikan nilai, maka siswa dengan sendiri akan terdorong untuk lebih giat lagi dalam belajar. Beberapa pertayaan kepada 
siswa kemudian siswa bersama teman-teman sekelompok-nya mencari jawaban dalam hal ini penjelasan dan pemecahan masalahnya lewat buku pegangan atau dengan menganalisis jawaban dari soal tersebut. Di akhir pelajaran, dilakukan evaluasi berupa tes essay, dan dari hasil evaluasi diperoleh 10 orang siswa yang mendapat nilai diatas 65 dengan pencapaian nilai rata-rata 64,6 atau secara klasikal $41,66 \%$.

Hal ini disebabkan karena siswa yang lain masih cenderung dengan bermain dalam kelompoknya dan hanya mengharapkan siswasiswa tertentu saja untuk menjawab atau memecahkan masalah berupa pertanyaan yang diberikan kepada setiap kelompok, siswa sering bermain sehingga kurang adanya konsentrasi dalam hal ini perhatian siswa terhadap materi yang diajarkan.

Menurut Gazali (dalam Slameto 2003:56) mengungkapkan bahwa untuk dapat menjamin hasil belajar yang baik, maka siswa harus mempunyai perhatian terhadap bahan yang dipelajarinya. Jika bahan pelajaran tidak menjadi perhatian siswa, maka timbullah kebosanan sehingga ia tidak suka lagi belajar.Agar siswa dapat belajar dengan baik, maka guru harus dapat membuat bahan pelajaran yang selalu menarik perhatian dengan cara mengusahakan pelajaran itu sesuai dengan hobby atau bakatnya.

Hasil evaluasi pada siklus I ini menunjukkan adanya peningkatan hasil belajar, karena sebelum diberikan tindakan hanya beberapa siswa yang memperoleh nilai diatas 65 oleh karena itu siswa belum mencapai ketuntasan belajar secara individu maupun klasikal. Siklus kedua sama halnya dengan siklus pertama, peneliti masih menggunakan model pembelajaran Cooperative Integrated Reading and Composition (CIRC) sebagai strategi pembelajaran. Pada siklus II ini peneliti lebih banyak memberikan penjelasan kemudian diiringi dengan pertanyaan yang dilemparkan kepada siswa yang selalu bermain bahkan mengganggu temannya pada saat pelajaran sedang berlangsung. Hal ini dikarenakan karena model pembelajaran Cooperative Integrated Reading and Composition (CIRC) merupakan suatu model pembelajaran yang mengharuskan setiap siswa aktif berinteraksi satu sama lain, sehingga suasana kelas tidak menjadi fokum dan informasi atau materi tidak hanya datang dari guru tetapi juga dari siswa.

Pada akhir pembelajaran diadakan evaluasi berupa tes essay dan dari hasil evaluasi diperoleh 24 orang siswa mendapat nilai diatas 65 dengan pencapaian nilai rata-rata 83,4 atau secara klasikal $87,5 \%$ artinya pada siklus kedua ini siswa sudah mencapai peningkatan hasil belajar. Ketuntasan belajar ini dilihat dari hasil siswa dalam kelompok dan hasil tes tertulis.Hal ini disebabkan karena siswa sudah aktif berbicara dalam kelompoknya dan memusat-kan perhatian terhadap materi yang diajarkan sehingga kegiatan belajar mengajar lebih efektif. Oleh karena itu, guru dalam mengajar harus dapat membuat situasi kelas yang nyaman sehingga siswa mampu untuk memperhatikan dan menerima materi yang diajarkan.

Ketika siswa yang nilainya masih dibawah atau belum mencapai ketuntasan belajar secara individual. 
Hal ini disebabkan karena selama proses belajar mengajar berlangsung siswa siswa ini tidak serius mendengarkan penjelasan karena sering tidak bersemangat dalam belajar, mengganggu siswa lain dalam belajar serta tergolong dalam siswa yang malas dan nakal dikelas.

Menurut (Dimyati dan $\mathrm{Mu}-$ djiono 2002:239) tentang sesuatu yang membawa diri sesuai dengan penilaian, adanya penilaian tentang sesuatu mengakibatkan terjadinya sikap menerima, menolak, atau mengabaikan. Sedangkan motivasi merupakan kekuatan mental yang mendorong terjadinya proses belajar. Lemahnya motivasi belajar akan melemahkan kegiatan belajar, sehingga mutu hasil belajar akan menjadi rendah, dan konsentrasi merupakan faktor penting yang berpengaruh dalam proses belajar.

\section{SIMPULAN}

Hasil analisis data menunjukkan bahwa proses pembelajaran Kemampuan Menulis Puisi Siswa SDN II Tomohon Sulawesi Utara terlihat meningkat dari waktu ke waktu. Terlihat sejak penilaian pembelajaran sebelum menggunakan pendekatan kontekstual hingga sesudah menggunakan pendekatan kontekstual, yaitu pada tahap Pra-observasi/pre-test dengan skor sebesar 1064, pada siklus I meningkat dengan skor 1182, siklus II meningkat dengan skor 1694, siklus III atau post-test meningkat dengan skor 2184.

Ketuntasan belajar yang dimulai dari tes awal sampai dengan siklus III telah menunjukkan peningkatan. Adapun peningkatan hasil tersebut dapat diuraikan sebagai berikut; nilai ketuntasan siswa pada tes awal
$3,85 \%$ dan tetap pada siklus I, kemudian meningkat menjadi $11,54 \%$ hingga akhirnya meningkat menjadi 96,15\% pada siklus III. Berdasarkan hasil pencapaian pada tindakan siklus III di mana hasil pencapaian pembelajaran sudah men-capai standar yang ditetapkan maka yang harus dilakukan adalah merefleksikan bahwa pembelajan menulis puisi siswa dengan pendekatan kontekstual melalui teknik CIRC sangat dibutuhkan dalam pembelajaran Bahasa Indonesia di SD. Dengan demikian dapat dikatakan bahwa dengan menggunakan pendekatan kontekstual dengan teknik CIRC sudah berhasil dalam meningkatkan kemampuan menulis Puisi siswa kelas V SD Negeri II Tomohon.

\section{REFERENSI}

Aminuddin. Pembelajaran Sastra sebagai Proses

Pemberwacanaan dan

Pemahaman Perubahan

Ideologi". Dalam Sudiro

Satoto dan Zainuddin Fananie (Eds.). Sastra: Ideologi, Politik, dan Kekuasaan (hlm. 45-55). Surakarta: University Muhamadiyah Press-HISKI Komisariat Surakarta. 2000.

Dharmojo, dkk. Sastra Lisan Ekagi. Jakarta: Pusat Pembinaan dan Pengembangan Bahasa. 1998.

Djuanda, D. Pembelajaran Keterampilan Berbahasa Indonesia di SD. Bandung: Pustaka Latifah. 2008

Emzir. Metodologi Penelitian Pendidikan Kualitatif dan Kuantitatif

Jakarta: PT. Raja Grafindo Persada. 2008 
Gani Rizanur. Pengajaran Sastra Respon dan Analisis. Jakarta:Depdikbud Dirjen Dikti PPLPTK. 1988.

Joni, T. Raka. Pengembangan Kurikulum IKIP/FIP/FKG (Studi Kasus Pendidikan Guru Berdasarkan Kompetensi. Jakarta:P3G Depdikbud. 1980.

Jabrohim (Ed.) Pengajaran Sastra. Yogyakarta: Kerja sama Pustaka Pelajar dan FPBS IKIP Muhammadiyah. 1994.

Karli, H-Margaretha. Model-model Pembelajaran. Bandung: CV Bina Media Informasi. 2004.

Kuswinarto. Dan Sastrawan pun Tak Lagi Percaya kepada Guru Sastra Dalam Asep S. 2001

Mansur, dkk. Dasar-dasar Interaksi Belajar Mengajar Bahasa Indonesia. Malang:Jemmare. 1987.

Muhardi (editor). Buku Kunjungan Akademik ke Bengkulu, Palembang dan Jambi Jurusan Pend. Bahasa dan Sastra Indonesia FPBS IKIP Padang. Padang: IKIP Padang Press. 1992.

Nasution, J.U., dkk. Minat Membaca Sastra Pelajar SMA Kelas III DKI Jakarta. Jakarta: Pusat Pembinaan dan Pengembangan Bahasa. 1981. Prayitno, Elida. Motivasi dalam Belajar. Jakarta :Depdikbud Dirjen Dikti PPLPTK. 1989.

Purwo, Bambang Kaswanti (Ed). Butir-Butir Sastra dan Bahasa Pemahaman Pengajaran. Yogyakarta: Kanisius. 1991.
Puar, Yusuf Abdullah. Setengah Abad Bahasa Indonesia. Jakarta: Idayus. 1989.

Rahman, A. Dkk. Kemampuan Apresiasi Puisi Murid SMA Jawa Timur. Jakarta: Pusat Pembinaan dan Pengembangan Bahasa. 1981.

Rahmanto, B. Metode Pengajaran Sastra. Yogyakarta: Kanisius. 1988.

Rosidi, Ajib. Pembinaan Minat Baca Apresiasi dan Penelitian Sastra. Jakarta: Panitia Tahun Buku Internasional. 1997.

Rusyana, Y. "Bahan Baku dan Pengolahan Bahan Pelajaran Sastra", makalah pada Seminar Pengelolalan Bahan Pelajaran Sastra dalam Buku Teks Bahasa dan Sastra Indonesia”. Dikumpulkan dalam Landasan Teori dan Pengolahan Bahan Pelajaran Sastra. Bandung: Program Pascasarjana IKIP Bandung. 1992.

Roestiyah. Strategi Belajar Mengajar. Jakarta: Rineka Cipta. 2008.

Sambodja Asep dkk. (Eds.). Cyber Graffiti Kumpulan Esai. Bandung: Yayasan Multimedia Sastra dan Angkasa. 2005 
BAHTERA: Jurnal Pendidikan Bahasa dan Sastra, Volume 16 Nomor 1 Januari 2017 http://journal.unj.ac.id/unj/index.php/bahtera/

ISSN : 0853-2710 